\title{
Can PA Governance Improve PA Outcomes: A Review of the Debates
}

\author{
Jones Lewis Arthur \\ Faculty of Applied Science and Technology, Sunyani Technical University, Sunyani, Ghana \\ Email: jonesarthur2002@yahoo.co.uk, jonesarthur2002@stu.edu.gh
}

How to cite this paper: Arthur, J. L. (2021). Can PA Governance Improve PA Outcomes: A Review of the Debates. Open Journal of Social Sciences, 9, 557-585. https://doi.org/10.4236/jss.2021.97040

Received: June 17, 2021

Accepted: July 27, 2021

Published: July 30, 2021

Copyright $\odot 2021$ by author(s) and Scientific Research Publishing Inc. This work is licensed under the Creative Commons Attribution International License (CC BY 4.0).

http://creativecommons.org/licenses/by/4.0/ (c) (i) Open Access

\begin{abstract}
Governance in the management of biodiversity conservation serves to provide people, particularly vulnerable human societies with opportunities for livelihood, recreation and renewal, water, food, clear air, the genetic potential of wild species, cultural values and visitor opportunities to nature sites. The paper explores protected area governance processes and structures, particularly; the link between improved governance and improved PA outputs. The main components of protected area (PA) governance (including legitimacy and voice, direction, performance, fairness and accountability) in respect to linking PA governance and improved PA outcomes were examined. The paper explores the content analysis methodology to examine the link between PA governance and PA outcomes from the perspective of management effectiveness. Content analysis is a useful tool for exploring issues such as PA governance and outcomes from the perspective of the qualitative content analysis to interpret the symbolic construction of meanings. The content analysis applied both quantitatively and qualitatively approaches to systematically analyze written, verbal or visual documentation to provide a better understanding of issues relating to PA governance and how it relates to PA outcomes. Content analysis was used to develop frames from the extant literature. The results were used to make inferences about the key issues and conclusions raised in the literature under broad frameworks developed from the categorization of the content in the extant literature. The paper identified that the application of effective PA governance is critical to achieving conservation outcomes. Good PA governance that complements PA outcomes works best when factors including the coherence of rules and decision-making processes, proper networks are built, and decentralization works and is fully backed by relevant institutional reforms. Good PA governance that complements PA outcomes works best when factors including the coherence of rules and decision-making processes, proper networks are built, and decentralization works and is fully backed by relevant institutional reforms.
\end{abstract}




\section{Keywords}

Protected Area, Governance, Legitimacy, Voice, Direction, Performance, Fairness, Accountability

\section{Introduction}

Biodiversity conservation continues to form an important basis for the Convention of Biological Diversity (CBD) to commit to reducing rates of biodiversity loss (Rands et al., 2010; Mace et al., 2018). Biodiversity Conservation serves many important purposes, provides people (particularly, vulnerable human societies) (Turner et al., 2012) with opportunities for livelihood, recreation and renewal, water, food, clear air, the genetic potential of wild species, cultural values and visitor opportunities to nature sites (Dudley, 2008); it is central to many beliefs and cultural values [important to local livelihood needs, development, and achievement of the United Nations Millennium Development Goals (MDGs)] (Convention on Biological Diversity, 2010).

Attempts at reducing biodiversity loss have led to several measures including the development of National Biodiversity Strategies and Action plan by the 193 CBD members, convening of international environmental meetings and writings on international biodiversity-related reports and accords that set biodiversity targets, and the establishment and expansion of the global network of parks and protected areas to include "over 12 per cent of the earth's terrestrial surface and 0.5 per cent of its marine systems" (Cardinale et al., 2012; Convention on Biological Diversity, 2004; Chape et al., 2005; UNEP-WCMC, 2008; Worboys \& Winkler, 2006: p. 3; Rands et al., 2010).

Globally, the competing interests of environmental conservation and development are real. Climate change accelerated resource depletion, and persistent poverty is critical challenge to biodiversity conservation, worldwide (World Resources Institute, 2003; Millennium Ecosystem Assessment, 2005; Rockström et al., 2009; Andam et al., 2010; UNDP, 2011; Vizzarri et al., 2015). For example, human activities have over the past 50 years rapidly and extensively undermined ecosystems: limits of global Climate change, rate of biodiversity loss, and nitrogen cycle (biogeochemical flow boundary) and the change has reached critical levels: Plant and animal disappearance are in the ranges of 100 to 1000 times more than the past mainly due to growing demands for food, fresh water, timber, and fuel (Millennium Ecosystem Assessment, 2005; Rockström et al., 2009); and over the decade, 25000 plants and more than a thousand species of animals are completely lost (Basilashvili, 2021). But, the degree of degradation and fragmentation of biodiversity loss varies considerably (El Balti, 2021). The effort to reduce biodiversity loss, influenced by ethical obligations, has historically led to two major approaches: 1) promoting restraint in the collection and consumption of wild species and their products, and 2) establishment and expansion of the 
global network of parks and protected areas to include "over 12 per cent of the earth's terrestrial surface and 0.5 per cent of its marine systems" (Chape et al., 2005; UNEP-WCMC, 2008; Worboys \& Winkler, 2006: p. 3). Decisions on nature management and use are not always fair and appropriate, as nature's benefits are not equitably shared, and richer countries and social elites become better placed to reap the benefits while poorer nations and communities bear the cost of biodiversity loss and get little or no benefit (IUCN, 2012). For example, effective PA governance has led to many successes; achieving greater coverage of PA (Convention on Biological Diversity, 2010; Walker et al., 2019); building networks leading to the protection of larger landscapes/seascapes (Nelson, 2010; Saura et al., 2018); realising effective conservation (Dudley, 2008; Baker et al., 2018); attaining greater savings and/or generation of resources to support visitations, and indigenous needs (Naughton-Treves, 2010: p. 235; Nelson, 2010); achieving resilient systems (Borrini-Feyerabend et al., 2006; Folke et al., 2005) and getting more people involved in conservation (Dudley, 2008; Clement \& Guerrero-Gonzalez, 2020). To strike a better balance, and make the two approaches workable makes the effectiveness of protected area (PA) governance critical. In PA governance (how power and responsibilities are exercised, a decision taken, and stakeholders held accountable), determines who controls the largest terrain in power distribution, allows other stakeholders to make inputs into decision making on matters concerning them, and regulates how different scales of government interact. Notwithstanding an increase in the global number and size of PA estates, the challenge of advancing conservation effectiveness of biodiversity, and ensure the success of PA governance remains.

Currently, many scholarships have recognized the usefulness of PA governance but, PAs and their governance processes and systems continue to face challenges (World Resources Institute, 2003; Millennium Ecosystem Assessment, 2005; Rockström et al., 2009; Andam et al., 2010; UNDP, 2011; Vizzarri et al., 2015; Basilashvili, 2021; El Balti, 2021). In this paper, various PA governance processes and structures are examined, particularly; the link between improved governance and improved PA outputs. The main components of PA governance (including legitimacy and voice, direction, performance, fairness and accountability) in respect to linking PA governance and improved PA outcomes will be examined.

\section{Methodology}

The paper explores the content analysis methodology to examine the link between PA governance and PA outcomes from the perspective of management effectiveness. Content analysis is a useful tool for exploring issues such as PA governance and outcomes from the perspective of the qualitative content analysis to interpret the symbolic construction of meanings (Neuendorf \& Kumar, 2015).

The content material on PA governance and how it supports attempts as pertains to different scales and time dimensions provide important guidelines for 
assessing PA outcomes. Content analysis is relevant to provide both quantitatively and qualitatively approaches to systematically analyze written, verbal or visual documentation to provide a better understanding of issues relating to PA governance and how it relates to PA outcomes (Wilson, 2016).

The content analysis was useful in helpful because key frames emerged from the analysis of extant literature for classification. The content was sourced from a variety of scope and sources including books, manuscripts, drawings, photographs, recorded conversations and online forums. The analysis involved breaking down the key issues of PA governance into conceptual chunks that are then organized into frames. The qualitative analysis was later developed into categories emphasizing issues including evolution, applications and relevance of $P A$, Why governance in protected area research (literature) and practice, $P A$ governance arrangements and effectiveness of $P A$ governance in achieving $P A$ outcomes.

The results were used to make inferences about the key issues and conclusions raised in the literature under broad frameworks developed from the categorization of the content in the extant literature.

The debates

Protected area governance in context; evolution, applications and relevance

\section{Protected area governance: An introduction}

Governance scholarship is diverse in scholarship. According to Stoker (1998), governance is concerned with the creation of conditions for ordered rule and collective action. Governance is also "about the ways and means in which the divergent preferences of citizens are translated into effective policy choices, and how the plurality of societal interests are transformed into unitary action and the compliance of social actors is achieved" (Kohler-Koch, 1999). Some contemporary scholars have contended that boundaries between state and society have become blurred just as the gap between public and private sections (Yu, 2018). Hence, governance emphasizes social coordination, shaping power relations and setting directions (Robinson, 2011). Consequently, governance concerns itself with decisions anticipated to promote the improvement of the management of key natural resources.

Governance is relatively recent in protected areas. It gained significant focus and scholarship at the Fifth Parks Congress in Durban in 2003 where it was identified as central to the conservation of PAs values (Borrini-Feyerabend, 2003; Dearden et al., 2005; Dudley, 2008). Thereafter, governance became an important theme in the World Conservation Congresses of Bangkok and Barcelona in 2004 and 2008 respectively. The Convention on Biological Diversity (CBD) Programme of Work on Protected Area (PWPA) also adopted governance in 2004 as one of the four (4) themes (governance, participation, equity and benefit-sharing) at the $7^{\text {th }}$ Conference of the Parties in Kuala Lumpur. In furtherance of these developments, the United Nations Development Programme (UNPD) proposed some key principles of good governance that have 
been synthesized and summarized by the Institute of Governance in (Table 1). Today, PA governance continues to be one of the central issues on the IUCN agenda. For example, the IUCN World Conservation Congress (WCC) in Jeju, Korea (September 2012) emphasize the need to close the gaps in governance and also focused on core themes of nature, climate, food, development, people, and life became one of the core themes (IUCN, 2012; The Jeju Weekly, 2012). Again, the 2012 WCC in Jeju emphasized the need to provide strong leadership in advocating for better and more equitable governance of the use of nature and natural resources. This emphasis on PA governance is motivated by the fact that decisions on nature management and use are not always fair and appropriate, as nature's benefits are not equitably shared, and richer countries and social elites become better placed to reap the benefits while poorer nations and communities bear the cost of biodiversity loss and get little or no benefit (IUCN, 2012). This is supported by the call for the inclusion of equity concerns (Aichi Target 11) to ensure equitable management for the world's protected areas (Dawson et al., 2018).

In this paper, PA governance refers to "the interactions among structures, processes and traditions that determine how power and responsibilities are exercised, how decisions are taken, and how citizens or other stakeholders have their say in the management of natural resources-including biodiversity conservation" (Graham et al., 2003: p. 2). Dudley (2008) indicates that good governance in PAs responds to principles and values that are freely chosen by the affected peoples of a country as "enshrined in their constitution, natural resource laws, PA legislation and policies and or cultural practices and customary laws" (Dudley, 2008; p. 28).

PA governance discourse has over the years, evolved in content and application including the dimensions of design, objectives and governance relationships.

PA evolution, design, objectives, governance relationships

Conservation of biodiversity is not new, but an evolving concept. The concept (protecting natural and semi-natural areas) dates back to thousands of years where a focus was on setting aside hunting areas (Guruug, 2010). But, it is important to note that conservation actions need to take into account the fact that

Table 1. Human rights principles and good governance as synthesized by UNDP and Institute of Governance (summarized from Graham et al., 2003).

\begin{tabular}{cc}
\hline Good Governance & UNDP principles \\
\hline Legitimacy and Voice & Participation, consensus building \\
Direction & Strategic planning \\
Performance & Responsiveness, effectiveness and efficiency \\
Accountability & Accountability, transparency \\
Fairness & Equity, rule of law \\
\hline
\end{tabular}


socio-ecological systems are always changing and, therefore, efforts at conservation planning in a rapidly changing global world should be dynamic in focus (Gavin et al., 2018). But, social norms, belief systems, and formal rules provide support for societies to regulate the access of individuals to environmental resources. Meanwhile, effective resource governance would depend on the categories and objectives of PA systems.

Global PA systems (categories and objectives) evolved as a result of the influence of the World Parks Congress (WPC) (Dudley, 2008). The result of the WPC is the IUCN definition of different types of PAs (Table 2), and the development and management of PAs (Locke \& Dearden, 2005; Dudley, 2008). PAs are of different sizes, age, purpose, designation, governance, management and outcomes (Dudley, 2008). Today, The World Database on Protected Areas (WDPA) recognizes 102,290 areas, covering 12.9\% of the Earth's land surface as being under some form of protection (Chape et al., 2005; UNEP-WCMC, 2008). But, there are arguments to suggest that majority of the additions to PA were to marine PAs. On average, 2.5 million $\mathrm{km}^{2}$ was added to the WDPA annually and 1.1 million $\mathrm{km}^{2}$ was removed (Lewis et al., 2019). By to achieve the 2020 Biodiversity Aichi target of $14.7 \%$ there must be a conscious effort to remove the rate of protected area removal to increase the rate of protected area designation and addition to the WDPA. Although protected areas differ in their usefulness, they collectively form an essential part of biodiversity conservation (Locke \& Dearden, 2005).

Table 2. IUCN protected area categories (summarized from Dudley, 2008).

\begin{tabular}{|c|c|}
\hline Category & Description \\
\hline & Area strictly set aside to protect biodiversity and \\
\hline 1a) Strict Nature & geological/geomorphological features; a human visitation, use and \\
\hline Reserve & impacts are strictly prohibited. \\
\hline 1b) Wilderness Area & $\begin{array}{l}\text { Large unmodified or slightly modified areas: protected and managed } \\
\text { to preserve their natural condition. }\end{array}$ \\
\hline & Large natural or near natural areas, protect large-scale ecological \\
\hline 2) National & processes and ecosystems; managed to provide a foundation for \\
\hline Park & $\begin{array}{l}\text { environmentally and culturally compatible spiritual, scientific, } \\
\text { educational, recreational and visitor opportunities. }\end{array}$ \\
\hline 3) Natural & Areas set aside to protect a specific natural monument. \\
\hline Monument & They are generally quite small and often with high visitor value. \\
\hline 4) Habitat/Species & $\begin{array}{l}\text { Aimed at protecting a particular species or habitats and management } \\
\text { reflects this priority. Many need regular and active interventions. }\end{array}$ \\
\hline $\begin{array}{l}\text { 5) Protected } \\
\text { Landscape/seascape }\end{array}$ & $\begin{array}{l}\text { Areas where people-nature interaction over time, has produced an } \\
\text { area of distinct character with significant ecological, biological, } \\
\text { cultural and scenic value. }\end{array}$ \\
\hline 6) Managed & $\begin{array}{l}\text { Aims to conserve ecosystems and habitats, together with associated } \\
\text { cultural values and traditional natural resource management systems; }\end{array}$ \\
\hline Resource & $\begin{array}{l}\text { It is generally large, mostly in the natural condition with a proportion } \\
\text { under sustainable natural resource management. }\end{array}$ \\
\hline
\end{tabular}


The different perceptions on PA governance have evolved through deliberation in the extant literature. These debates have resulted into the call to further explore effective ways to apply effective PA governance to achieve better PA management/governance outcomes.

Why governance in protected area research (literature) and practice?

In the past, formal PAs were protected against the activities of hunters, loggers and miners, as well as provide access to justice that solves conflicts associated with the activities of indigenous people and local communities (Worboys \& Winkler, 2006; Zafra-Calvo et al., 2017). This more traditional approach has often undermined community livelihoods, through the displacement of people and denial of access to natural resources vital to human needs (Krueger, 2009; Naughton-Treves, 2010). In Latin America and Sub-Saharan Africa, for example, over $85 \%$ of all protected area establishments were associated with state expropriation of customary tribal lands, dismantling of villages and exiling communities (Hess, 2001; Lockwood, 2010). Experiences from some PAs in East and Central Africa (where indigenous and traditional communities were unwelcomed and denied their needs) led to poaching, illegal logging, and also reduced revenue from parks (Murphree, 1991; Nelson \& Agrawal, 2008). The experience has been a norm in other places, worldwide; marred park-community relationships, and aggravated poverty among neighbouring communities of parks (Nelson \& Agrawal, 2008; Naughton-Treves, 2010).

Good governance serves as a requirement to securing effective management of PA systems; it is fundamental to "securing the political and community support essential to development, indeed the survival, of the global protected area system" (Lockwood, 2010: p. 755). Good governance is becoming increasingly important for the legitimacy of state institutions including PA systems (Addink, 2019). The conservation environment ideology is changing to encourage the local population to value and participate in the protection of natural resources (Murphree, 1991; Nelson \& Agrawal, 2008; Nelson, 2010; Dotan et al., 2017). The need to establish and maintain good governance (across a diversity of ownership and responsibility arrangement) is vital for the future acceptance and effectiveness of PAs (Lockwood, 2010). The need to ensure that there is a collective interest in conservation, and secure and understand the socio-economic and cultural benefits of surrounding communities and stakeholders is yet another reason driving the emergence of governance in PA research.

Recent attempt to dominate PA management with a top-down model (in especially, many developing countries) has met various forms of resistance, contestation, and replacement by forms of partnership, collaborative and shared management, and community arrangements (Lockwood, 2010). Active centralized ownership of resources such as wildlife, forest, and fisheries has resulted in poor transparency in the procedures for allocation of wildlife use (hunting) concessions, and overall governance (Nelson \& Agrawal, 2008). With a greater role of governments and their agencies in power and responsibilities, local and indigenous communities, non-governmental agencies, individual landowners, 
often collaborate in various types of partnerships (Kothari, 2006; Lockwood, 2010; Foo, 2018). But, of key concern is the gradient of partnership relationships in the shared relationship (Baghai et al., 2018).

The turn of effects to recognize and respect local and indigenous rights when experiences in many parts of the world, was influenced by the fact that PA establishment has led to the displacement of people who also later become disadvantaged (Krueger, 2009; Lockwood, 2010; Campbell \& Gray, 2019). Improvements in international and regional conventions on human rights have provided ethical reasons for PAs to uphold and incorporate multi-stakeholder rights, roles, and interests in PA management. Previously, PA had often led to the loss of access to lands for farming and fishing, including the loss of some free forms of nature (snails, shea butter seeds, and firewood) with dire consequences like poverty, that threaten human existence (United Nations, 2010; Campbell \& Gray, 2019). Addressing these forms of unfairness and inequity of PA benefits to communities are important reasons to explore governance as a way to gain the acceptance and support of wider stakeholders such as civil societies.

Attempts to apply a top-down approach to $\mathrm{P}$ governance have been problematic as it has led to low capacities, unsustainable resource extraction, poaching, sabotage, and incursions from local communities (Lockwood, 2010). Active state-centred ownership of natural resources has led to deforestation in some PAs; this is evident in Indonesia, Guatemala, Honduras, Mexico, Belize, Costa Rica, Jamaica, India, Brazil, Zimbabwe, Malawi and Malaysia, where over $90 \%$ of PAs are managed by the government (Porter-Bolland et al., 2012). This was different in other forests resources where a mix of formal and informal arrangement led to lower deforestation trends and also deterred deforestation in many PAs in the tropics especially, in the South American tropics (Porter-Bolland et al., 2012). But, poorly integrated restoration-related policies may have negative consequences or poor attention to key influences from different scales (Mansourian, 2017). In reality, when PAs are effectively managed, it contributes to conservation (Dearden et al., 2005). Presently, PA governance is more into devolving top-down regulatory policies to integrate management under common property, private and civil society arrangements (Rands et al., 2010). To bring on board different actors and attain conservation goals will require the application of different roles in PA governance.

In recent times, the informed citizenry (through increased education, and enhanced communication and mobility) has pressed for a greater say in decisions that affect their lives including, the designation and management of PAs (Kothari, 2006; Lockwood, 2010; Heuva, 2019). Consumers (as emerging important new agents in environmental policy) and environmental activists are choosing to exercise collective power (often coordinated by transnational non-governmental organizations) to boycott polluters and poor labour practices to purchase products from companies with better environmental and social standards (Liverman, 2004; Speer \& Han, 2018). The development has spearheaded the emergence of more powerful and significantly performing NGOs, private and communi- 
ty-based environmental actors in PA governance (Lockwood, 2010). Participatory management is emerging as legislation and policy require a development motivated by increased levels of community involvement in PA issues (Dearden et al., 2005). Environmental activists in countries as varied as Malaysia, India, Thailand, Brazil, Nigeria, and Kenya (Tinga et al., 2020), have fought against international corporations to protect their forests and rivers, promote sustainable development, safeguard biodiversity from the onslaught of transnational seed companies and other forces of globalization; and paralleled the movement for environmental justice in the USA (Mertig \& Dunlap, 2001; Goyes \& South, 2017). These actions are also supported by the commitment of the world (through WCC) to still commit to species recovery, strengthen breeding programmes already in place, and promote leadership for better and more equitable governance (The Jeju Weekly, 2012). Good governance helps civic society and citizens to gain knowledge to support nature conservation.

In the past 30 years, significant changes have occurred under the caption of neoliberalism (suggesting that the costs of pollution and environmental degradation should be included in the market and that private property is preferred for efficient resource management) (Liverman \& Vilas, 2006). Governments, among other things, have devolved responsibilities from government agencies to individuals and communities and favoured market-based instruments (Lockwood, 2010). Again, neoliberalism is complemented by the current global shift towards the commodification of nature and the reworking of environmental governance (Liverman, 2004; Debelo et al., 2018). Application of governance in current PA management is important since efforts to conserve nature has been largely undermined by world trade and neoliberalism that creates easy opportunities for natural resources to be traded.

In the recent past, governance has assumed significance in PA research as a result of the recognition that many protected areas problems require a landscape-scale approach response (Lockwood, 2010; Comer et al., 2020). Substantial numbers of protected areas continue to be created in areas inhabited by indigenous and local communities which incidentally, are also home to some of the world's poorest citizens, who in many cases depend on forests "for income or as a safety-net during natural disasters or periods of social strife" (Naughton-Treves, 2010: p. 235). To address the wider connectivity of PAs, governance is needed to establish conditions under which successful and unsuccessful local initiatives and win-win solutions can occur because, "synergistic solutions can be advanced or tradeoffs made between biodiversity and development goals" (Timmer, 2005: p. 9). The challenge to engage with and influence policy responses across diverse transboundary arrangements and "networks of state, sub-state, non-state and civil society organizations" makes PA governance critical (Lockwood, 2010: p. 755). PA governance will support effective conservation for PA and surrounding areas since conservation and local objectives can be integrated to produce a win-win result for all.

As part of conflict resolution strategies, governance has been singled out as a 
critical tool (Zadek \& Raynard, 2017). Issues of democracy that promote human rights, respect consensus and participation have been strongly advocated for resolving conflicts in human societies (United Nations, 2010; Pierce, 2018). Consequently, governance at multi-scalar and stakeholder levels is advocated for appropriating power and responsibilities, effective decision-making, and accountability in PA management (Borrini-Feyerabend, 2003; Pierce, 2018). In the "fight" to claim fairness, legitimacy, and accountability among others, governance has over the past 10 years, become "popular" in PA research literature.

\section{PA governance: The main issues}

The previously dominant state-based top-down model of PA governance has been debated, and in some cases replaced, by decentralized forms of collaborative management, partnership arrangements, delegated authority and community management (Lockwood, 2010). More so, the governance of PAs has been characterized by various issues. Whilst some scholarships have challenged PA governance based on decision-making authority, and tenure arrangements, others have also argued against the roles and responsibilities of various actors of PA governance. The foundation of the dissenting views has ranged between past histories of PAs and arrangement of socio-economic policies, to the ever-changing world influenced by knowledge and information. Governance opens one's mind to the possibility that groups in society other than government (e.g. communities or the voluntary sector) may have to play a stronger role in addressing PA problems (Graham et al., 2003). Also, governance is centred on good, credible information about stocks, flows, and processes within the resource systems targeted, and also the human-environment interactions that affect the systems (Diatz et al., 2003). Hence, knowledge forms one of the major underlying forces of PA governance. For effective governance, information about values, uncertainties, and the state of the environment and human actions is required (Diatz et al., 2003; Akamani, 2019). This section will review some of the important issues in PA governance.

\section{Decision-making authority}

In recent times, PAs range from full control (by a state agency) to control by other interest; but this has shifted from where the government is the sole decision-making authority to decision by consultation (Ward et al., 2018). For example in Indonesia, Guatemala, Honduras, Mexico, Belize, Costa Rica, Jamaica, India, Brazil, Zimbabwe, Malawi and Malaysia, over $90 \%$ of PAs are managed by the government (Porter-Bolland et al., 2012). Likewise, over $86 \%$ of world forest and woodland areas are being managed by central governments (Nelson, 2010). However, important improvements (lower deforestation trends) are evident in areas where little was owned by other arrangements outside formal government ownership (Porter-Bolland et al., 2012). The issue of decision making authority to the government including the distribution of powers over PAs, is still evident in PA literature.

\section{Distribution of Powers over PAs}

Power (an important issue in PA governance) is central to the differences in 
the various types of governance, and a larger extent, instrumental to the success or failure of associated PA objectives. In a PA, power determines who (citizens, media, public sector, civil societies, and the government) controls the largest terrain in power distribution (Graham et al., 2003; Khan et al., 2019). It is now a common practice for power to be shared between government and non-government actors because governance is all-inclusive (concerned with how other actors including civil society organization, have inputs into decision making on matters of public concern and how different scales of government interact) (Graham et al., 2003; Kothari, 2006). But public-private cooperation is not prevalent in national parks within centralized countries because stakeholders are likely to have different stakes in a shared governance arrangement (Ly \& Zhang, 2019).

Planning, regulatory, revenue mobilization, spending, and power to enter into agreements are the five types of power identified as important to PA governance (Graham et al., 2003). These types of power as held by different actors dictate the roles and responsibilities of different actors. The appropriation of these types of power to a larger extent determines how power is held by the various actors, responsibilities and roles of the actors, and to a greater extent the governance type. For example, experiences in Zambia, Mozambique, Tanzania, and Kenya have shown that because the government still retains a larger share of power, processes to devolve ownership and control of wildlife resources to local communities have not been that successful (Nelson \& Agrawal, 2008; Ntuli et al., 2020). This development has dared some supporters of community-based natural resource management to argue that, such initiatives have failed to deliver (Nelson, 2010). In PA management, power has become critical because it determines who controls the largest terrain in power distribution, how other stakeholders make inputs into decision making on matters concerning them, and how different scales of government interact. Linked to these propositions has been the need to better define protected area values.

Governance principles. Defining protected area values

Governance principles are essential to PA governance because it provides the guide to assessing the quality of governance (Graham et al., 2003). It is important to mention that the fifth World Parks Congress (WPC) at the fifth congress argued to an end to exclusionary approaches to conservation; recognition of customary forms of environmental protection; the need to restore the losses to indigenous peoples whose lands were incorporated into protected areas without meaningful consent; and development of rights-based approaches to conservation (Witter \& Satterfield, 2019). One significant categorization of governance came from Graham et al. (2003) where governance was grouped under five broad groups (starting point of the UNDP guide of good governance) as in Table 1. These principles enable performance to be assessed and compared to different governance settings; basically, because different aspects of governance vary in different settings, and societies value outcomes differently. This brings to the fore, debates on what should constitute values, cultural norms, and social and economic outcomes. The World Parks Congress stresses the need to recog- 
nize and support different types of governance and the involvement of various stakeholders in arks governance (Witter \& Satterfield, 2019).

Good governance principles of governance are not "watertight" as they may overlap and sometimes reinforce one another. The conflicting issue may crop up, thus calling for a balance of judgment in the application of the principle (Graham et al., 2003). In such circumstances, such as complexities, an understanding of the social context (history, culture and technology) will be important to determine a balance, and how these principles play in practice (Graham et al., 2003). Allowing the different actor roles to play will be needed to determine, understand and define what makes up good governance in a particular situation (Graham et al., 2003; Borrini-Feyerabend et al., 2006; Witter \& Satterfield, 2019). PA governance principles provide a guide for measuring governance effectiveness for different outcomes and settings but, these principles can vary or reinforce each other.

Devolution and decentralization as ways to understand $P A$ governance

Experiences in some PA discourse have shown evidence of government tendency to retain considerable power; hence weakening opportunities for communities to invest and conserve wildlife. The process of transferring government decision-making and administrative authority (decentralization) to other actors of PA such as communities has increased over the past 30 years. This process has become necessary because 1) Governments are seeking to implement their policies and programs in a more cost-effective, responsive and equitable manner and to increase overall social benefits and 2) Citizens are demanding more influence on decisions affecting their lives and, as appropriate, the redressing of past injustices (Borrini-Feyerabend, 2003; Kothari, 2006). An understanding of the different supportive democratic and human rights context, appropriate degree of decentralization in decision making, scope and depth of participation by people who depend on resources, the existence of social groups, high levels of trust, better monitoring of outcomes, stronger enforcement of property rights, governance arrangements, and investment in institutional capacities at local, regional, and national levels are critically important for effective PA governance (Agrawal et al., 2008; Dudley, 2008; Witter \& Satterfield, 2019). The progress in decentralization is undermined by developments including some government (e.g. Sub-Saharan Africa) hijacking (direct or indirect) the ownership and control of natural resources. Devolution and decentralization improve PA governance by increasing cost efficiency, increasing local participation in PA, and building trust between government and other stakeholders of PAs.

Institutional dimensions of natural resource use: tenure arrangement and property rights

Understanding local resource tenure arrangements of PAs is relevant for good governance in PAs because; resource tenure and property rights determine who may access and use a resource or capture the resource value (Nelson, 2010). But, from the community welfare's perspective, land resources management should increase the efficiency of its natural resources, no matter who is in charge of 
managing the resource (Ahene, 2020). These arrangements (resource tenure and property rights are captured by formal and informal institutions. Institutions are the rules (formal and informal) that govern society and underpin human economic activities and social interactions, and also shape the distribution of rights over natural resources (Nelson, 2010). Formal institutions (laws, policies, and constitutions) help to define, distribute and delimit the powers of states and citizens whilst informal institutions (norms, customs, and ethical beliefs) govern human behaviours through rules of social interaction (Nelson, 2010). In a situation where rights over resources are undefined or unenforced, conditions of open access (commons) tend to encourage resource depletion because nobody will be motivated to conserve resource which is available for use by any prospective user (Hardin, 1968; Baird \& Dearden, 2003; Nelson, 2010; Epstein, 2017).

The choice of appropriate right to tenure arrangement and institution for PAs should take into cognizance the prevailing local situations because they provide relevant local practices that serve biodiversity conservation better (Baird \& Dearden, 2003; Nelson \& Agrawal, 2008). It is important to note that, under certain circumstance, state orientation is still useful notwithstanding shifts from state to people-centred governance arrangements (Baird \& Dearden, 2003). It is recommended that $\mathrm{PA}$ governance types must appreciate the context of each PA, and come out with the most appropriate management strategies including governance effectiveness, that provides a win-win for the achievement of the goals of the particular PA and local population (Baird \& Dearden, 2003). For example, in Ratanakiri, Cambodia resource such as Dipterocarp trees (for harvesting re$\sin$ ) have been privately owned for generation whilst land is communally owned (Baird \& Dearden, 2003). This ownership arrangement helped to protect these trees and ensure sustainable harvest compared to Malva trees (communally owned) that attracted unsustainable use because resources were over-harvested (Baird \& Dearden, 2003). In these circumstances, the communal ownership of land prevented it from being traded to outsides; private tenure of Resin tree fiercely prevented outside loggers from cutting it down; whilst communal tenure of Malva tree led to its misuse (Baird \& Dearden, 2003). Effective management of PAs resources with varied ownership and user rights will need tenure and institutional arrangement that incorporate local situation and practices that serve the best interest for biodiversity conservation.

\section{Protected area governance: the arrangements}

Diverse new governance models beyond the traditional direct management by government agencies have lexperimented in recent years. Protected area governance ranges "from the traditional exercise of government authority, through to a wide variety of partnership, co-management and informal arrangements involving multiple agencies, NGOs, communities, and individuals" (Lockwood, 2010: p. 762). These have included various forms of collaborative management by local communities or indigenous people, and those delegated by third parties such as NGOs and the private sector (Graham et al., 2003; Borrini-Feyerabend et al., 2006; Kothari, 2006; Witter \& Satterfield, 2019). As a follow-up to the fifth 
World Parks Congress in Durban, four main governance models were identified, recognized by the IUCN, and based on decision-making, ownership, management authority, and responsibilities. The discussions are as follows:

Government protected areas

The government managed PAs is run by a federal/national/agency in charge, sub-national ministry, or delegated to an NGO (Dudley, 2008). Usually, a government has extensive control in power relationships, decision making, and accountability in a government-managed PA and also regulates the control of power, decisions and accountability depending on the type of control of power, decision making and accountability it intends to apply (Graham et al., 2003). Such agencies determine conservation objectives, develop and enforce management plans, and most often own protected area resources (Dudley, 2008; Guruug, 2010). A state-managed PA usually provides equity and fair application of governance as a prime objective to the larger population (Kothari, 2006). Under such an arrangement, the government may delegate responsibilities to a parastatal, NGO, private operator or community (Dudley, 2008; Guruug, 2010). The government managed PA aids in providing equity and fair application of governance for many actors because roles and responsibilities may be delegated to other actors.

Collaborative managed protected areas

A shared PA governance approach involves the sharing of decision-making, and power between state agencies and other partners including but not limited to local communities and indigenous peoples, NGOs and individuals, and private sector institutions (Kothari, 2006). In each of the management arrangements, however, there are clearly defined interests, roles, responsibilities and processes of accountability which may be exercised through collaborative, joint or transboundary management (Dudley, 2008). In collaborative management "formal decision-making authority, responsibility and accountability may rest with one agency (often a national governmental agency)" but by law, the agency needs to collaborate with other stakeholders (Kothari, 2006: p. 119; Khan et al., 2017). Transboundary PAs (PAs that transcend national boundaries) are better managed in shared governance because these PAs have both local and international implications for their management (Kothari, 2006; Dotan et al., 2017). For example, shared governance or multi-stakeholder governance is effective for the management of transboundary PA resources (where transboundary management or joint management board can be applied) and brings the knowledge and influence of different stakeholder to bear on the management of the PA (Dudley, 2008). Shared management is criticised because it is difficult to apply different (country regulations) management approaches to a transboundary PA (e.g. wilderness areas) that cuts across national borders. However, establishing joint management boards to oversee the management of such PA stand to provide some successes (Dudley, 2008). Examples of Collaborative managed PAs are Galapagos Marine Reserve, Ecuador (Borrini-Feyerabend, 2003). Shared governance is very effective for involving different stakeholders with different inter- 
ests to contribute to PA management effectiveness.

\section{Private management}

As part of the IUCN PA governance types, Private management is designated for PAs that are declared and run by private individuals, and/or Non-Governmental Organizations (NGOs) for for-profit or non-profit purposes e.g. Pantanal, Brazil (Borrini-Feyerabend, 2003; Bingham et al., 2017). The private management of these PAs have no governmental involvement but IUCN PA categories are applied (Dudley, 2008). These private parties legally own the PA resources, determine conservation objectives, develop and enforce management plans and remain in charge of decisions (Dudley, 2008; Guruug, 2010; Bingham et al., 2017). The management approach is critiqued on the basis that, effective management will require the negotiation of incentives from the government in return for specific levels of accountability by the private management (Dudley, 2008). Private managed PA provides effective management because stakeholders are accountable to the traditional community who incidentally share in the ownership of the PA.

\section{Community Conserved Areas (CCAs)}

In traditional community management, authority and responsibility for managing the particular resource and territory rests with the "indigenous peoples and/or local communities" who also possesses customary/legal claims to the land with collective management (Borrini-Feyerabend, 2003: p. 6; Tobin, 2017). The territories and resources are cited as CCA instead of "protected area" because PA erroneously connotes some form of governmental control (Dudley, 2008). Traditional communities have been managing nature sites and species for quite a long time; but "the fact that these are equivalent in many ways to conventional government-managed 'protected areas' has not been recognized until recently" (Kothari, 2006: p. 549). Examples of indigenous managed parks are Sacred lakes in Coron, Philippines and New Sacred forests in India managed by local communities (Borrini-Feyerabend, 2003; Samakov \& Berkes, 2017). CCAs worldwide have been known to produce some of the best management effectiveness for protected areas as it helps in improving revenue, reduce corruption, and empower communities to get involved in local PA management (Murphree, 1991; Nelson \& Agrawal, 2008; Corrigan et al., 2018). This approach is advantageous because it usually leads to improved conservation practices. After all, the control of power and decision making is in the hands of the indigenous or traditional local community (Dudley, 2008). The criticism against this approach stems from the fact that it fails to produce good results and rather encourage exploitation by other stakeholders like tour companies, undermines the legitimate rights of indigenous peoples and local communities because, the knowledge and experience of the community to make informed inputs into the PA management are sometimes low (Nelson \& Agrawal, 2008; Zurba et al., 2019). CCA is important for PA management effectiveness because it encourages local and indigenous people to own and participate in the management of PA resources. 


\section{Effectiveness of PA governance in achieving PA outcomes}

Quite recently, good governance has gained significant attention as a conservation priority. It can support the IUCN biodiversity conservation priorities of "long term conservation of nature, ecological resources and its associated cultural values" (Dudley, 2008: p. 8). Conservation priorities are summarized into nature conservation, science, visitor opportunities (recreation, educational, cultural, spiritual), and local and indigenous needs (Graham et al., 2003) as well as reconcile development with conservation in a recent increasing number of international initiatives (Kennedy et al., 2019). Achieving PA outcomes through PA management effectiveness has gained grounds because achieving the outcomes is taken as part of the theory and practice of monitoring and evaluation of PAs (Borrini-Feyerabend et al., 2006). Several evaluation methodologies have been developed for evaluating PA governance effectiveness. These include; Management Effectiveness developed by IUCN-WCPA, Framework for Governance Effectiveness (Lockwood, 2010) and Conservation Action Planning (Leverington et al., 2008).

The available methodologies and indicators are not "limited" but still emerging; it includes the different schools of thoughts on how best to address the issues of global declining biodiversity undermined by anthropogenic causes. Some conservationists who favour "strict conservation" argue for more attention to biodiversity conservation in all aspects of PA design, implementation, and governance (Locke \& Dearden, 2005; Miller et al., 2011; Robinson, 2011; Zhang et al., 2020). Conservationists have continually debated biodiversity priorities; whether wildlife, wilderness, or other natural assets should be prioritized over development for aesthetic, moral, or spiritual reasons (human welfare) (Miller et al., 2011). Others are rather of a pro-development orientation and advocate for various forms of sustainable use and conservation-oriented development and welfare-oriented goals such as poverty reduction and social justice (Nelson, 2010). Others scholars have also debated good governance providing enough reasons for achieving PA outcomes (Graham et al., 2003; Borrini-Feyerabend, 2003; Borrini-Feyerabend et al., 2006; Kothari, 2006; Lockwood, 2010; Eklund et al., 2017; Helliwell et al., 2018). Leverington et al. (2010) for instance is of the view that it is possible to have PAs degrading and at the same time meeting their outputs. Similarly, a badly managed PA can maintain its broader values. Assessing good governance to investigate its capacity to deliver social benefits, conservation goals including the protection of biodiversity and ecosystem values is important. Good governance (founded upon the capacity and reliability of governing institutions to effectively respond to problems and achieve social unity through various forms of consultation, negotiation and multi-party agreements) is a fair and effective way of exercising governing powers (means) to meet the objectives (ends) of the protected area (Borrini-Feyerabend et al., 2006; Helliwell et al., 2018). Asserting the effectiveness of various methodologies for assessing PA effectiveness requires a focus on options that serve conservation objectives best since different methodologies have different perspectives for either strict 
conservation or a mix of conservation-development objectives.

Greater coverage of areas important for biodiversity and ecosystem functioning

Good PA governance supports efforts at meeting targets for greater coverage of areas important to biodiversity and ecosystem functioning. When the full suite of governance types is applied and leads to marked support for achieving an expansion of areas that can support biodiversity and ecosystem functions. In such cases, governance (where governance is by indigenous peoples and local communities, by the private sector and in shared governance arrangements) can be recognized, either as a component of the official protected area system or through other means. The CBD targets 17 and 18 (exploring and applying traditional knowledge, innovations and practices of indigenous and local communities relevant for the conservation and sustainable use of biodiversity) need to be balanced with livelihoods and other development goals (Convention on Biological Diversity, 2010). The engagement of actors outside of government is likely to increase the social acceptability and sustainability of the overall PA system. Drawing from arguments by Lockwood, opportunities available for all stakeholders to participate and influence decision processes and output can clarify diverse interests and values, reduce project failures, enhance public ownership and commitment to solutions, and build capacity to manage competing interests and mediate conflicts (Lockwood, 2010). Good governance has improved revenue and indigenous and local community needs and encouraged active participation of local communities in wildlife management in Community Based Natural Resource Management (CBNRM) areas in East and South Africa (Nelson \& Agrawal, 2008; Mbaiwa et al., 2019; Walker et al., 2019). Good governance encourages active local participation in PAs and leads to the commitment of local communities to increase coverage of areas that protect biodiversity and ecosystem functioning.

Build networks of protected areas leading to protection of larger landscapes/ seascapes

Effective PA governance has a greater ability to build networks and promotes connectivity of protected areas leading to the protection of larger landscapes/seascapes. PA governance promotes connectivity across a different scale and geographic regions (Lockwood, 2010; Saura et al., 2018). Strategic connectivity (in an environment of multilevel governance and for regional sustainability development) allows different actors of PAs to build shared recognition of interdependencies among PA issues and allows for the sharing of problems in a concerted manner. By this, local, sub-national, national, and international PA governance actors build mutual respect, trust and cohesion to collectively work to address the full range of PA values and concerns such as connecting areas physically, counteract fragmentation, maintain species movement and migratory pathways, and allow for genetic exchange and other benefits of connectedness (Lockwood, 2010; Saura et al., 2018). Many community conserved areas (for example the community forests in New Hampshire, USA and the Van Panchayat 
forests in Uttarakhand, India) are serving as corridors between two or more government-protected areas (Borrini-Feyerabend et al., 2006). In the Serengeti Ecosystems, effective networking and connectivity have allowed for the protection of wildlife and ecosystems over large landscapes, and across different physical and institutional boundaries (Nelson, 2010). In 2005, Ghana completed an inventory of 3000 sacred groves over the national territory as a result of the development of by-laws that recognized traditional forms of conservation. An improved institution (law enforcement) also led to a high reduction in poaching and forest destruction at Kakum Conservation Area, Ghana (IUCN, 2012). Good PA governance can increase the trust of communities in PA arrangements, and motivate them to commit more wilderness areas to the PA network.

\section{More effective conservation}

Achieving the conservation goals of a protected area will greatly depend on how and by whom management decisions are being made and implemented. When local actors are involved in decision-making, it results in greater acceptance and public support for the protected area. In addition, transparent and accountable decision-making institutions may effectively carry out conservation measures, adopt adaptive management and provide timely and adequate responses to changing conditions. The control of power and decision making in the Community Conserved Area (CCA), which usually lead to the achievement of effective conservation practices, is in the hands of the indigenous or traditional local community (Dudley, 2008; Baker et al., 2018). CCAs worldwide have been known to produce some of the best management effectiveness for protected areas (Murphree, 1991; Nelson \& Agrawal, 2008; Baker et al., 2018). Similarly, an enhancement of skills and knowledge of local actors in PAs for the Aboriginal peoples of Australia (who have unique knowledge on how to manage landscapes through timely, controlled fires) promoted the conservation of wildlife and ecosystems hitherto being destroyed by wildfires (Borrini-Feyerabend et al., 2006). Policy reforms and legal reforms carried out in Tanzania in the 1990s enabled local communities to formalize collective actions in the forest leading to widespread ecological recoveries (Nelson, 2010). Again, centralized PA governance in Kenya in 1970 made Kenya a major country in east and southern Africa with a sizeable wildlife population that does not allow any commercial hunting (Nelson \& Agrawal, 2008). Good PA governance empowers local communities to support effective conservation.

Greater savings andlor generation of resources to support visitations, and indigenous and community needs

Effective PA governance has a significant effect on promoting greater savings and/or generation of resources through visitor opportunities (recreational, educational, cultural, spiritual) and local and indigenous needs. PA governance within the protected area system is a cost-effective conservation measure since it recognizes what is already in place (such as existing institutional arrangements and conservation efforts by private landowners or communities), avoids some of the social or financial cost of governments in regularizing land tenure arrange- 
ment (stepping in to buy land or impose regulations) (Borrini-Feyerabend et al., 2006). Zimbabwe's Community Areas Management Programme for Indigenous Resources (CAMPFIRE) programme has resulted in over $\$ 20$ million in revenues from wildlife captures at districts and community levels for 1989-2001 (Nelson, 2010). Decentralized governance models can also save resources by devolving decision-making to the local level and reducing administrative costs; especially useful because world's poorest citizens, who in many cases depend on forests "for income or as a safety-net during natural disasters or periods of social strife" making of PA a key focus for management effectiveness (Naughton-Treves, 2010: p. 235). "win-win" outcomes are feasible when public programmes that provide employment and capacity development are pursued alongside conservation goals (e.g. South Africa's Working for Water programme) (Borrini-Feyerabend et al., 2006). At the level of individual protected areas, participatory processes (through the investment of time and resources) are usually cost-effective in the long run, as they reduce conflicts, harness the contributions of local actors in conservation, and reduce the need for cost-intensive enforcement measures.

Resilient systems supported by effective PA governance

All governance institutions (formal and informal) may go through periods of instability, dysfunction or inactivity. Effective governance provides support in detecting and responding to environmental feedback such that; it contributes to ecological knowledge and understanding of ecosystem processes and functions necessary for addressing threats and pressures in a social-ecological system (Folke et al., 2005). For instance, the Community Reserve of Lac Telé-Likuoala aux Herbes, in the Republic of Congo (used to be a State-governed protected area) was previously government-managed PA until abandoned by state agencies during Congo's era of political instability (Borrini-Feyerabend et al., 2006). The engagement of multiple institutions in protected area governance provides a buffer against the failure of any one institution.

\section{More people actively involved in conservation}

Expansion of actors involved in PA governance such as trust-run protected areas is initiated and managed by, or rely on help from informed private individuals. When people are actively involved in biodiversity conservation, their experience, understanding and insights into conservation are used to enhance, and support relevant issues (conservation efforts) and action of society (Dudley, 2008; Nelson, 2010; Clement \& Guerrero-Gonzalez, 2020). In the United States, conservation NGOs have encouraged landowners to group together and create conservation Trusts (with or without concurrent land easements or servitudes) in exchange for tax incentives from state governments. Similarly in the UK, over a million private individuals are members of the Royal Society for the Protection of Birds, allowing the organization to run over 200 protected areas (Borrini-Feyerabend et al., 2006). Good governance is a good conduit to motivate more people into the conservation of nature.

Does effective PA governance always lead to PA outcomes?

Expansion of $P A$ area versus Conservation outcomes 
The pressure to expand PAs to meet international targets such as Aichi Target 11 may have 2 choices in how limited funds are spent. PA expansion without enhanced enforcement will always deliver diminishing marginal returns (Kuempel et al., 2018). Expansion of PA estates does not always lead to the achievement of conservation outcomes. Active engagement of various actors in PA governance, and building institutional capacities does not always promote biodiversity conservation. For example, the addition of "new categories" $\mathrm{V}$ and VI of PA which emphasize sustainable use of natural ecosystems, does not primarily serve the objective of biodiversity protection because the characterization of category VI PA has openly motivated some countries to categorize forest areas protected for logging, as protected areas (Locke \& Dearden, 2005). The addition to the "new category" V and VI, in reality, tends to inflate the size of PAs when these large areas are classified as PAs (Locke \& Dearden, 2005: p. 3). For example, categories V and VI PAs have led to logging of trees, and oil exploration in British Columbia and the USA respectively rather than primarily contributing to the conservation of biodiversity (Locke \& Dearden, 2005). For example, global protected area expansion is compromised by projected land use and parochialism (Pouzols et al., 2014). For effective management, PA categories V and VI have to be classified as Sustainable Development Areas (SDAs). This will eliminate the confusion and distraction caused by PA category V and VI so that, they can play a vital and complementary role in biodiversity conservation in PA, and protection of human values including poverty reduction (Locke \& Dearden, 2005). Good governance has led to PA categories V and VI fails to adequately support nature conservation.

Challenge of applying PA governance at different scales, rules versus principles

Developing and applying a set of governance principles in abstraction is plausible, however; the application in the "real" context is challenging (Graham et al., 2003). Culture, history, technology in a parliamentary, congressional, or context of some other system of government challenges the success of governance principles (Graham et al., 2003; Lockwood, 2010). At the landscape level, the main challenge is how to decide on the optimal allocation for best outcomes (De Groot et al., 2010). Improving governance at one scale does not guarantee improvement at another scale. Achieving effective, sustainable environmental governance demands a better understanding of the causes and consequences of the complex patterns of interdependencies that tend to connect people and ecosystems within and across scales (Bodin et al., 2019). The reality applies when comparing options (from global to ecosystem level), and rules versus principles.

The process of rule-making (an important element of governance) and rules together define relationships within a society and this, in reality, is the essence of governance. The success of rule-making applies in the phase of flexible rules because that allows for creativity and entrepreneurship in the application of the rules (Graham et al., 2003). This process would ensure good rules in an environment of good principles, and with the governance principles serving as ref- 
erence points. Around the world, many governments have adopted the rhetoric of decentralization, devolution, and local empowerment, but this has not complemented institutional reforms relevant for effective application (Nelson, 2010). In many places across Africa, Asia and Latin America, centralized governments have maintained discretionary control over valuable natural resources, and local tenure arrangement leading to more efficiency and better representation (Nelson, 2010; Ribot, 2021). In most countries in Central and South Africa, the level of local participation in policy reforms has not supported wildlife sector reform outcomes to date. There is also little evidence of significant bottom-up influence in institutional processes in these countries; for example, active civic and locally-based reform lobby has been unsuccessful in producing wildlife sector reforms in Kenya (Nelson \& Agrawal, 2008).

The same principle applies in many countries where the drive to support neoliberalism (motivated by current global take towards the commodification of nature and reworking of environmental governance) creates a conflict of development versus conservatism in PA governance applications (Liverman, 2004; Nelson, 2010; Speer \& Han, 2018). In many African countries, world trade directions have driven massive destruction of wildlife, wilderness areas, and destructions of marine resources through a subtle agenda by the development world, to promote trade and development in African (Liverman, 2004; Liverman \& Vilas, 2006; Nelson, 2010). In many such cases, the application of effective PA governance becomes just a guideline in abstract but, practically challenging.

Comparing options. governance effectiveness in global to ecosystem level

It is no doubt that protected areas face a diverse range of governance issues at different governance perspectives (global, agency-wide, individual PAs and ecosystem levels) (Graham et al., 2003). A global solution may not necessarily be accepted and applied to a local context due to the different level of impacts at global, national, individual PAs and ecosystem levels. For example, improved governance cannot halt climate change impact on amphibians. PA governance in this circumstance cannot necessarily reduce species loss at Marine Protected Area (MPA) because different governance arrangements apply at different scales, whereas, impacts may be localized and sometimes drive externalities into other areas (Graham et al., 2003; Mansourian, 2017). Decentralization, which is to promote good governance, can also result in fragmented, unrepresentative and undemocratic institutions and processes that open opportunities for actors to satisfy private interest as against the provision of public good (Lockwood, 2010). Today, there are failed attempts to encourage China to reduce pollutions from its industries and also adopt cleaner technologies that have minimal impact on climate change (e.g. melting of polar ice that threatens the habitats of polar bears, and expose them to human impacts). Good governance at the global level has also not succeeded in convincing governments in most forest regions of the world (e.g. Africa, and South America) to engage in the active protection of forest resources, afforestation, and re-afforestation drive to serve as carbon sinks that reduce climate change impacts, worldwide (Di Sacco et al., 2021; Wainaina 
et al., 2020).

\section{Conclusion}

The application of effective PA governance is critical for achieving conservation outcomes. Again, PAs and their governance arrangements continue to face socio-economic, historical, political and ecological challenges. Debates on whether PAs management should target strict conservation or a mix of conservation and socio-economic, and welfare interest of humans continue to emerge. Today, the debates have included PA governance such as; whether good governance ensures the achievement of PA outcomes. The results are diverse since PA issues are embedded in complex socio-ecological systems, which require solution specific to context to be developed, tested and applied. In other cases, it has become clear that prescribing specific governance guidelines to address PA effectiveness and achieve conservation outcomes are at best applicable in abstraction and not in practice. Good PA governance that complements PA outcomes works best when factors including the coherence of rules and decision-making processes, proper networks are built, and decentralization works and is fully backed by relevant institutional reforms. The case is not always positive because PAs and their challenges cut across global perspectives, institutional objectives, and individual PA values. In sum, there is no direct link between improved governance and the attainment of conservation objectives.

\section{Conflicts of Interest}

The author declares no conflicts of interest regarding the publication of this paper.

\section{References}

Addink, H. (2019). Good Governance: Concept and Context. Oxford University Press. https://doi.org/10.1093/oso/9780198841159.001.0001

Agrawal, A., Chhatre, A., \& Hardin, R. (2008). Changing Governance of the World's Forests. Science, 320, 1460-1462. https://doi.org/10.1126/science.1155369

Ahene, R. A. N. (2020). Customary Tenure Trusteeships and Land Governance Reforms: A Necessary Convergence. African Journal on Land Policy and Geospatial Sciences, 3, 1-12.

Akamani, K. (2019). Rethinking Sustainable Development Using Deep Ecology and Adaptive Governance of Social-Ecological Systems: Implications for Protected Areas Management. Preprints, 2019, 2019080066.

Andam, K. S., Ferraro, P. J., Sims, K. R., Healy, A., \& Holland, M. B. (2010). Protected Areas Reduced Poverty in Costa Rica and Thailand. Proceedings of the National Academy of Sciences of the United States of America, 107, 9996-10001. https://doi.org/10.1073/pnas.0914177107

Baghai, M., Miller, J. R., Blanken, L. J., Dublin, H. T., Fitzgerald, K. H., Gandiwa, P. et al. (2018). Models for the Collaborative Management of Africa's Protected Areas. Biological Conservation, 218, 73-82. https://doi.org/10.1016/j.biocon.2017.11.025

Baird, I. G., \& Dearden, P. (2003). Biodiversity Conservation and Resource Tenure Re- 
gimes: A Case Study from Northeast Cambodia. Environmental Management, 32, 541-550. https://doi.org/10.1007/s00267-003-2995-5

Baker, D. M., Murray, G., \& Agyare, A. K. (2018). Governance and the Making and Breaking of Social-Ecological Traps. Ecology and Society, 23, 38.

https://doi.org/10.5751/ES-09992-230138

Basilashvili, T. (2021). Forest Cover for the Safety of Biosphere and Environment. In M. Öztürk, V. Altay, \& R. Efe (Eds.), Biodiversity, Conservation and Sustainability in Asia (pp. 355-370). Springer. https://doi.org/10.1007/978-3-030-59928-7 13

Bingham, H., Fitzsimons, J. A., Redford, K. H., Mitchell, B. A., Bezaury-Creel, J., \& Cumming, T. L. (2017). Privately Protected Areas: Advances and Challenges in Guidance, Policy and Documentation. Parks, 23, 13-28.

https://doi.org/10.2305/IUCN.CH.2017.PARKS-23-1HB.en

Bodin, Ö., Alexander, S. M., Baggio, J., Barnes, M. L., Berardo, R., Cumming, G. S. et al. (2019). Improving Network Approaches to the Study of Complex Social-Ecological Interdependencies. Nature Sustainability, 2, 551-559.

https://doi.org/10.1038/s41893-019-0308-0

Borrini-Feyerabend, G. (2003). Governance of Protected Areas-Innovation in the Air. Policy Matters, 12, 12-103.

Borrini-Feyerabend, G., Johnston, J., \& Pansky, D. (2006). Governance of Protected Areas. In M. Lockwood, G. Worboys, \& A. Kothari (Eds.), Managing Protected Areas: A Global Guide (pp. 116-145). Earthscan.

Campbell, L. M., \& Gray, N. J. (2019). Area Expansion versus Effective and Equitable Management in International Marine Protected Areas Goals and Targets. Marine Policy, 100, 192-199. https://doi.org/10.1016/j.marpol.2018.11.030

Cardinale, B. J., Duffy, J. E., Gonzalez, A., Hooper, D. U., Perrings, C., Venail, P. et al. (2012). Biodiversity Loss and Its Impact on Humanity. Nature, 486, 59-67. https://doi.org/10.1038/nature11148

Chape, S., Harrison, J., Spalding, M., \& Lysenko, I. (2005). Measuring the Extent and Effectiveness of Protected Areas as an Indicator for Meeting Global Biodiversity Targets. Philosophical Transactions: Biological Sciences, 360, 443-455.

http://www.jstor.org/stable/30040906

https://doi.org/10.1098/rstb.2004.1592

Clement, S., Guerrero Gonzalez, A., \& Wyborn, C. (2020). Understanding Effectiveness in Its Broader Context: Assessing Case Study Methodologies for Evaluating Collaborative Conservation Governance. Society \& Natural Resources, 33, 462-483. https://doi.org/10.1080/08941920.2018.1556761

Comer, S., Clausen, L., Cowen, S., Pinder, J., Thomas, A., Burbidge, A. H. et al. (2020). Integrating Feral Cat (Felis catus) Control into Landscape-Scale Introduced Predator Management to Improve Conservation Prospects for Threatened Fauna: A Case Study from the South Coast of Western Australia. Wildlife Research, 47, 762-778. https://doi.org/10.1071/WR19217

Convention on Biological Diversity (2004). The 2020 Biodiversity Target: A Framework for Implementation. CBD COP 7 Secretariat.

Convention on Biological Diversity (2010). Linking Biodiversity Conservation and Poverty Alleviation: A State of Knowledge Review. CBD Technical Series, No. 55.

Corrigan, C., Bingham, H., Shi, Y., Lewis, E., Chauvenet, A., \& Kingston, N. (2018). Quantifying the Contribution to Biodiversity Conservation of Protected Areas Governed by Indigenous Peoples and Local Communities. Biological Conservation, 227, 
403-412. https://doi.org/10.1016/j.biocon.2018.09.007

Dawson, N., Martin, A., \& Danielsen, F. (2018). Assessing Equity in Protected Area Governance: Approaches to Promote Just and Effective Conservation. Conservation Letters, 11, e12388. https://doi.org/10.1111/conl.12388

De Groot, R. S., Alkemade, R., Braat, L., Hein, L., \& Willemen, L. (2010). Challenges in Integrating the Concept of Ecosystem Services and Values in Landscape Planning, Management and Decision Making. Ecological Complexity, 7, 260-272.

https://doi.org/10.1016/j.ecocom.2009.10.006

Dearden, P., Bennett, M., \& Johnston, J. (2005). Trends in Global Protected Area Governance. Environmental Management, 36, 89-100. https://doi.org/10.1007/s00267-004-0131-9

Debelo, A. R., Klute, G., \& Detona, M. (2018). “They Have Stolen Our Land” Enclosure, Commodification and Patterns of Human-Environment Relations among Afar Pastoralists in Northeastern Ethiopia. Modern Africa: Politics, History and Society, 5, 127-150. https://doi.org/10.26806/modafr.v5i2.199

Di Sacco, A., Hardwick, K. A., Blakesley, D., Brancalion, P. H., Breman, E., Cecilio Rebola, L. et al. (2021). Ten Golden Rules for Reforestation to Optimize Carbon Sequestration, Biodiversity Recovery and Livelihood Benefits. Global Change Biology, 27, 1328-1348. https://doi.org/10.1111/gcb.15498

Diatz, T., Ostrum, E., \& Stern, P. (2003). The Struggle to Govern the Commons. Science, 302, 1907-1912. https://doi.org/10.1126/science.1091015

Dotan, P., Yeshayahu, M., Gordon-Kirsch, N., Groisman, L., Al-Khateeb, N., Rabbo, A. A. et al. (2017). Endocrine Disrupting Compounds in Streams in Israel and the Palestinian West Bank: Implications for Transboundary Basin Management. Journal of Environmental Management, 204, 355-364. https://doi.org/10.1016/j.jenvman.2017.09.017

Dudley, N. (Ed.) (2008). Guidelines for Applying Protected Area Management Categories. IUCN. https://doi.org/10.2305/IUCN.CH.2008.PAPS.2.en

Eklund, J. F., \& Cabeza-Jaimejuan, M. D. M. (2017). Quality of Governance and Effectiveness of Protected Areas: Crucial Concepts for Conservation Planning. Annals of the New York Academy of Sciences, 1399, 27-41. https://doi.org/10.1111/nyas.13284

El Balti, N. (2021). Heathland, Scrub and Savanna: Overview, Recent Trends and Outlook. In C. Hobohm (Ed.), Perspectives for Biodiversity and Ecosystems (pp. 361-381). Springer. https://doi.org/10.1007/978-3-030-57710-0_15

Epstein, G. (2017). Local Rulemaking, Enforcement and Compliance in State-Owned Forest Commons. Ecological Economics, 131, 312-321. https://doi.org/10.1016/j.ecolecon.2016.09.012

Folke, C., Hahn, T., Olsson, P., \& Norberg, J. (2005). Adaptive Governance of Social-Ecological Systems. Annual Review of Environment and Resources, 30, 441-473.

https://doi.org/10.1146/annurev.energy.30.050504.144511

Foo, K. (2018). Examining the Role of NGOs in Urban Environmental Governance. $\mathrm{Ci}$ ties, 77, 67-72. https://doi.org/10.1016/j.cities.2018.01.002

Gavin, M. C., McCarter, J., Berkes, F., Mead, A. T. P., Sterling, E. J., Tang, R., \& Turner, N. J. (2018). Effective Biodiversity Conservation Requires Dynamic, Pluralistic, Partnership-Based Approaches. Sustainability, 10, 1846.

https://doi.org/10.3390/su10061846

Goyes, D. R., \& South, N. (2017). The Injustices of Policing, Law and Multinational Monopolization in the Privatization of Natural Diversity: Cases from Colombia and Latin America. In D. Rodríguez Goyes, H. Mol, A. Brisman, \& N. South (Eds.), Environ- 
mental Crime in Latin America (pp. 187-212). Palgrave Macmillan. https://doi.org/10.1057/978-1-137-55705-6 9

Graham, J., Amos, B., \& Plumptre, T. (2003). Governance Principles for Protected Areas in the 21st Century: A Discussion Paper Institute of Governance/Parks Canada/Canadian International Development Agency.

Guruug, H. (2010). Trends in Protected Areas. CRC for Sustainable Tourism Pty Ltd.

Hardin, G. (1968). The Tragedy of the Commons. Science, 162, 1243-1244. https://doi.org/10.1126/science.162.3859.1243

Helliwell, J. F., Huang, H., Grover, S., \& Wang, S. (2018). Empirical Linkages between Good Governance and National Well-Being. Journal of Comparative Economics, 46, 1332-1346. https://doi.org/10.1016/j.jce.2018.01.004

Hess, K. (2001). Parks Are for People-But Which People? In T. Anderson, \& A. James (Eds.), The Politics and Economics of Park Management (pp. 159-181). Rowman and Littlefield.

Heuva, W. E. (2019). Deferring Citizens' "Right to Know" in an Information Age: The Information Deficit in Namibia. In Information Resources Management Association (Ed.), Journalism and Ethics: Breakthroughs in Research and Practice (pp. 264-286). IGI Global. https://doi.org/10.4018/978-1-5225-8359-2.ch017

IUCN (2012, October 7). Nature, People, and Governance. IUCN World Conservation Congress.

Kennedy, C. M., Oakleaf, J. R., Theobald, D. M., Baruch- Mordo, S., \& Kiesecker, J. (2019). Managing the Middle: A Shift in Conservation Priorities Based on the Global Human Modification Gradient. Global Change Biology, 25, 811-826. https://doi.org/10.1111/gcb.14549

Khan, B., Tervo, N., Pärssinen, A., \& Juntti, M. (2019, September). Statistical Linearization of Phased Arrays Using Power Adaptive Power Amplifier Model. In 2019 IEEE 30th Annual International Symposium on Personal, Indoor and Mobile Radio Communications (PIMRC) (pp. 1-5). IEEE. https://doi.org/10.1109/PIMRC.2019.8904111

Khan, H. F., Yang, Y. C., Xie, H., \& Ringler, C. (2017). A Coupled Modeling Framework for Sustainable Watershed Management in Transboundary River Basins. Hydrology and Earth System Sciences, 21, 6275-6288. https://doi.org/10.5194/hess-21-6275-2017

Kohler-Koch, B. (1999). The Evolution and Transformation of European Governance. In B. Kohler-Koch, \& R. Eising (Eds.), The Transformation of Governance in the European Union. Routledge.

Kothari, A. (2006). Collaborative Managed Protected Areas. In M. Lockwood, G. Worboys, \& K. Kothari (Eds.), Managing Protected Areas: A Global Guide. Earthscan.

Krueger, L. (2009). Protected Areas and Human Displacement: Improving the Interface between Policy and Practice. Conservation and Society, 7, 21-25. https://doi.org/10.4103/0972-4923.54793

Kuempel, C. D., Adams, V. M., Possingham, H. P., \& Bode, M. (2018). Bigger or Better: The Relative Benefits of Protected Area Network Expansion and Enforcement for the Conservation of an Exploited Species. Conservation Letters, 11, e12433. https://doi.org/10.1111/conl.12433

Leverington, F., Costa, K., Pavese, H., Lisle, A., \& Hockings, M. (2010). A Global Analysis of Protected Area Management Effectiveness. Environmental Management, 46, 685-698. https://doi.org/10.1007/s00267-010-9564-5

Leverington, F., Hockings, M., Pavese, H., Costa, K. L., \& Courrau, J. (2008). Management Effectiveness Evaluation in Protected Areas-A Global Study. Supplementary 
Report No. 1: Overview of Approaches and Methodologies. The University of Queensland.

Lewis, E., MacSharry, B., Juffe- Bignoli, D., Harris, N., Burrows, G., Kingston, N., \& Burgess, N. D. (2019). Dynamics in the Global Protected-Area Estate Since 2004. Conservation Biology, 33, 570-579. https://doi.org/10.1111/cobi.13056

Liverman, D. (2004). Who Governs, at What Scale and at What Price? Geography, Environmental Governance, and the Commodification of Nature. Annals of Association of American Geographers, 94, 734-738.

Liverman, D. M., \& Vilas, S. (2006). Neoliberalism and the Environment in Latin America. Annual Review of Environment and Resources, 31, 327-363.

https://doi.org/10.1146/annurev.energy.29.102403.140729

Locke, H., \& Dearden, P. (2005). Rethinking Protected Area Categories and the New Paradigm. Environmental Conservation, 32, 1-10. https://doi.org/10.1017/S0376892905001852

Lockwood, M. (2010). Good Governance for Terrestrial Protected Areas: A Framework, Principles and Performance Outcomes. Journal of Environmental Management, 91, 754-766. https://doi.org/10.1016/j.jenvman.2009.10.005

Ly, T. P., \& Zhang, C. (2019). Why Public-Private Cooperation Is Not Prevalent in National Parks within Centralised Countries. Asia Pacific Journal of Tourism Research, 24, 1109-1125. https://doi.org/10.1080/10941665.2019.1666154

Mace, G. M., Barrett, M., Burgess, N. D., Cornell, S. E., Freeman, R., Grooten, M., \& Purvis, A. (2018). Aiming Higher to Bend the Curve of Biodiversity Loss. Nature Sustainability, 1, 448-451. https://doi.org/10.1038/s41893-018-0130-0

Mansourian, S. (2017). Governance and Forest Landscape Restoration: A Framework to Support Decision-Making. Journal for Nature Conservation, 37, 21-30. https://doi.org/10.1016/j.jnc.2017.02.010

Mbaiwa, J. E., Mbaiwa, T., \& Siphambe, G. (2019). The Community-Based Natural Resource Management Programme in Southern Africa-Promise or Peril?: The Case of Botswana. In M. Mkono (Ed.), Positive Tourism in Africa (pp. 11-22). Routledge.

Mertig, A., \& Dunlap, R. (2001). Environmentalism: Preservation and Conservation. In N. J. Smelser, \& P. B. Baltes (Eds.), International Encyclopedia of the Social \& Behavioral Sciences (pp. 4687-4693). Pergamon. https://doi.org/10.1016/B0-08-043076-7/04154-1

Millennium Ecosystem Assessment (2005). Ecosystems and Human Well-Being: Current State and Trends: Findings of the Condition and Trends Working Group. Island Press.

Miller, T. R., Minteer, B. A., \& Malan, L. (2011). The New Conservation Debate: The View from Practical Ethics. Biological Conservation, 144, 948-957. https://doi.org/10.1016/j.biocon.2010.04.001

Murphree, M. W. (1991). Communities as Institutions for Resource Management. CASS Occasional Paper Series, CASS.

Naughton-Treves, L. (2010). Participatory Zoning to Balance Conservation and Development in Protected Areas. In J. Ingram, F. DeClerck, \& C. Rumbaitis del Rio (Eds.), Integrating Ecology and Poverty Reduction: The Application of Ecology in Develop ment Solutions (pp. 235-251). Springer. https://doi.org/10.1007/978-1-4614-0186-5 17

Nelson, F. (2010). Introduction: The Politics of Natural Resource Governance in Africa. In F. Nelson (Ed.), Community Rights, Conservation and Contested Land: The Politics of Natural Resource Governance in Africa (pp. 3-31). Earthscan.

Nelson, F., \& Agrawal, A. (2008). Patronage or Participation? Community-Based Natural 
Resource Management Reform in Sub-Saharan Africa. Development and Change, 39, 557-585. https://doi.org/10.1111/j.1467-7660.2008.00496.x

Neuendorf, K. A., \& Kumar, A. (2015). Content Analysis. In The International Encyclopedia of Political Communication (pp. 1-10). John Wiley \& Sons. https://doi.org/10.1002/9781118541555.wbiepc065

Ntuli, H., Muchapondwa, E., \& Okumu, B. (2020). Can Local Communities Afford Full Control over Wildlife Conservation? The Case of Zimbabwe. Journal of Choice Modelling, 37, Article ID: 100231. https://doi.org/10.1016/j.jocm.2020.100231

Pierce, J. (2018). Sustainability, Justice, and the Problem of Scale: Place-Making as a "Multi-Scalar Fix" in Urban Environmental Politics. In T. Marsden (Ed.), The SAGE Handbook of Nature. SAGE Publications Ltd. https://doi.org/10.4135/9781473983007.n19

Porter-Bolland, L., Ellis, E. A., Guariguata, M. R., Ruiz-Mallen, I., Negrete-Yankelevich, S., \& Reyes-Garcia, V. (2012). Community Managed Forests and Forest Protected Areas: An Assessment of Their Conservation Effectiveness across the Tropics. Forest Ecology and Management, 268, 6-17. https://doi.org/10.1016/j.foreco.2011.05.034

Pouzols, F. M., Toivonen, T., Di Minin, E., Kukkala, A. S., Kullberg, P., Kuusterä, J. et al. (2014). Global Protected Area Expansion Is Compromised by Projected Land Use and Parochialism. Nature, 516, 383-386. https://doi.org/10.1038/nature14032

Rands, M. R., Adams, W. M., Bennun, L., Butchart, S. H., Clements, A., Coomes, D. et al. (2010). Biodiversity Conservation: Challenges beyond 2010. Biodiversity Conservation Science, 329, 1298-1303. https://doi.org/10.1126/science.1189138

Ribot, J. (2021). Representation, Citizenship and the Public Domain: Choice and Recognition in Natural Resource Decentralization. In G. Crawford, \& A.-G. Abdulai (Eds.), Research Handbook on Democracy and Development (pp. 503-521). Edward Elgar Publishing. https://doi.org/10.4337/9781788112659.00041

Robinson, L. (2011). Environmental Governance as If Value Matter: Communities and Conservation in Africa.

Rockström, J., Steffen, W., Noone, K., Persson, A., Stuart III Chapin, F., Lambin, E. et al. (2009). Planetary Boundaries: Exploring the Safe Operating Space for Humanity. Ecology and Society, 14, 32. https://doi.org/10.5751/ES-03180-140232

Samakov, A., \& Berkes, F. (2017). Spiritual Commons: Sacred Sites as Core of Community-Conserved Areas in Kyrgyzstan. International Journal of the Commons, 11, 422-444. https://doi.org/10.18352/ijc.713

Saura, S., Bertzky, B., Bastin, L., Battistella, L., Mandrici, A., \& Dubois, G. (2018). Protected Area Connectivity: Shortfalls in Global Targets and Country-Level Priorities. Biological Conservation, 219, 53-67. https://doi.org/10.1016/j.biocon.2017.12.020

Speer, P. W., \& Han, H. (2018). Re-Engaging Social Relationships and Collective Dimensions of Organizing to Revive Democratic Practice. Journal of Social and Political Psychology, 6, 745-758. https://doi.org/10.5964/jspp.v6i2.929

Stoker, G. (1998). Governance as Theory: Five Propositions. International Social Science, 50, 17-28. https://doi.org/10.1111/1468-2451.00106

The Jeju Weekly (2012, October 8). Jeju Declaration adopted at 2012 World Conservation Congress. The Jeju Weekly. http://www.jejuweekly.com/news/articleList.html

Timmer, V. (2005). Biodiversity Conservation and Poverty Reduction Come Together in the Tropic: Lessons Learned from the Equator Initiative. Environment, 47, 24-44.

https://doi.org/10.3200/ENVT.47.4.24-44

Tinga, T. M., Murphy, P. D., \& Sessou, E. S. (2020). ICTs, Environmental Activism and 
Community Mobilization in Senegal, Kenya and South Africa. In J. Díaz-Pont, P. Maeseele, A. Egan Sjölander, M. Mishra, \& K. Foxwell-Norton (Eds.), The Local and the Digital in Environmental Communication (pp. 129-149). Palgrave Macmillan. https://doi.org/10.1007/978-3-030-37330-6 7

Tobin, B. (2017). Where Custom Is the Law: State and User Obligations to "Take into Consideration" Customary Law Governing Traditional Knowledge and Genetic Resources. In C. R. McManis, \& B. Ong (Eds.), Routledge Handbook of Biodiversity and the Law (pp. 291-309). Routledge. https://doi.org/10.4324/9781315530857-19

Turner, W. R., Brandon, K., Brooks, T. M., Gascon, C., Gibbs, H. K., Lawrence, K. S. et al. (2012). Global Biodiversity Conservation and the Alleviation of Poverty. BioScience, 62, 85-92. https://doi.org/10.1525/bio.2012.62.1.13

UNDP (2011). Human Development Report 2011 Sustainability and Equity: A Better Future for All. UNDP.

UNEP-WCMC (2008). State of the World's Protected Areas: An Annual Review of Global Conservation Progress. UNEP World Conservation Monitoring Centre.

United Nations (2010). MDG Progress Report; Keeping the Promise: A Forward Review to Promote an Agreed Action Agenda to Achieve the Millennium Development Goals by 2015. United Nations.

Vizzarri, M., Tognetti, R., \& Marchetti, M. (2015). Forest Ecosystem Services: Issues and Challenges for Biodiversity, Conservation, and Management in Italy. Forests, 6, 1810-1838. https://doi.org/10.3390/f6061810

Wainaina, P., Minang, P. A., Gituku, E., \& Duguma, L. (2020). Cost-Benefit Analysis of Landscape Restoration: A Stocktake. Land, 9, 465. https://doi.org/10.3390/land9110465

Walker, L., Avery, K., Borgerhoff Mulder, M., Gohil, D., King, J., Lalampaa, T. et al. (2019). Supporting Community-Based Natural Resource Management in Pastoralist Societies in East Africa to Achieve the UN Sustainable Development Goals. University of Exeter.

Ward, C., Holmes, G., \& Stringer, L. (2018). Perceived Barriers to and Drivers of Community Participation in Protected-Area Governance. Conservation Biology, 32, 437-446. https://doi.org/10.1111/cobi.13000

Wilson, V. (2016). Research Methods: Content Analysis. Evidence-Based Library and Information Practice, 11, 41-43. https://doi.org/10.18438/B8CG9D

Witter, R., \& Satterfield, T. (2019). The Ebb and Flow of Indigenous Rights Recognitions in Conservation Policy. Development and Change, 50, 1083-1108. https://doi.org/10.1111/dech.12456

Worboys, G., \& Winkler, C. (2006). Natural Heritage. Managing Protected Areas, a Global Guide. IUCN.

World Resources Institute (2003). The Wealth of the Poor: Managing Ecosystems to Fight Poverty. World Resources Institute.

Yu, K. P. (2018). Governance and Good Governance: A New Framework for Political Analysis. Fudan Journal of the Humanities and Social Sciences, 11, 1-8. https://doi.org/10.1007/s40647-017-0197-4

Zadek, S., \& Raynard, P. (2017). Partnership Alchemy: Engagement, Innovation and Governance. In S. Zadek, \& P. Raynard (Eds.), Tomorrow's History (pp. 253-266). Routledge.

Zafra-Calvo, N., Pascual, U., Brockington, D., Coolsaet, B., Cortes-Vazquez, J. A., Gross-Camp, N. et al. (2017). Towards an Indicator System to Assess Equitable Management in Protected Areas. Biological Conservation, 211, 134-141. 
https://doi.org/10.1016/j.biocon.2017.05.014

Zhang, J., Yin, N., Li, Y., Yu, J., Zhao, W., Liu, Y. et al. (2020). Socioeconomic Impacts of a Protected Area in China: An Assessment from Rural Communities of Qianjiangyuan National Park Pilot. Land Use Policy, 99, Article ID: 104849.

https://doi.org/10.1016/j.landusepol.2020.104849

Zurba, M., Beazley, K. F., English, E., \& Buchmann-Duck, J. (2019). Indigenous Protected and Conserved Areas (IPCAs), Aichi Target 11 and Canada's Pathway to Target 1: Focusing Conservation on Reconciliation. Land, 8,10 .

https://doi.org/10.3390/land8010010 